\title{
REBOISASI JALUR LINGKAR WILIS : SEBUAH USAHA MEMPERTAHANKAN DAERAH RESAPAN AIR DI KABUPATEN TULUNGAGUNG JAWA TIMUR
}

\section{REFORESTATION OF JALUR LINGKAR WILIS: AN EFFORT TO MAINTAIN THE WATER PERMEATING AREA IN TULUNGAGUNG DISTRICT EAST JAVA}

\author{
Wahyu Perdana ${ }^{1}$, Muhammad Sururi ${ }^{1}$, Fansurina Erdayanti ${ }^{1}$, Vida Brilian ${ }^{1}$, \\ Amalia Ristanti ${ }^{1}$, Devi Listiani ${ }^{1}$, Gandul Atik Yuliani $^{2}$, Wiwin Retnowati ${ }^{3}$ \\ ${ }^{1}$ Mahasiswa KKN Universitas Airlangga, ${ }^{2}$ Fakultas Kedokteran Hewan, ${ }^{3}$ Fakultas \\ Kedokteran Universitas Airlangga \\ email: wiwin-r@fk.unair.ac.id
}

\begin{abstract}
Jalur Lingkar Wilis is a road which is connecting six cities in East Java Province, throughout Nganjuk, Ponorogo, Madiun, Tulungagung, Trenggalek, and Kediri. This road was placed along the foothill of Wilis Mountain which is this location was part of a protected forest and located in Geger Village, Sendang Sub - District. Therefore, some parts of protected forests face deforestation as the consequence of the Jalur Lingkar Wilis construction. This deforestation made the total of trees in Wilis Mountain decrease to worried conditions and cause the water absorption area in Tulungagung also fall on decreation. According to this condition, it takes awareness from all of the stakeholders to maintain the water absorption area through reforestation. This activity is in collaboration between Universitas Airlangga students with Perhutani, KPHLS Sendang, and Tulungagung Society to prepare and execute this reforestation. By the reforestation 220 trees were planted along the Jalur Lingkar Wilis. The reforestation is expected to prevent the protected forest area in Wilis Mountain from environmental damage as the consequence of Jalur Lingkar Wilis construction and also protect the water availability in Tulungagung.
\end{abstract}

Keywords: reforestation, Jalur Lingkar Wilis, water absorption

abstrak

Jalur Lingkar Wilis adalah jalur yang menghubungkan enam kabupaten di Jawa Timur, mulai dari Kabupaten Nganjuk, Ponorogo, Kabupaten Madiun, Tulungagung, Trenggalek, dan Kediri. Jalur ini melewati daerah kaki Gunung Wilis yang merupakan daerah hutan lindung yang terletak di Desa Geger, Kecamatan Sendang. Hal ini membuat sebagian wilayah dari hutan lindung harus mengalami penggundulan sebagai konsekuensi dari pembangunan Jalur Lingkar Wilis. Sehingga pohon-pohon di sekitar Jalur Lingkar Wilis mengalami penurunan jumlah yang mengkhawatirkan. Permasalahan tersebut menyebabkan daerah resapan air di Kabupaten Tulungagung mengalami penurunan, sehingga diperlukan kesadaran semua pihak untuk mengembalikan dan mempertahankan daerah resapan air dengan cara reboisasi. Kegiatan ini merupakan kerjasama mahasiswa Universitas Airlangga dengan Perhutani, KPHLS Tulungagung, dan Tulungagung Society. Hasil dari kegiatan reboisasi ini tertanam sejumlah 220 bibit pohon pule, petai, nangka, dan alpukat di sepanjang Jalur Lingkar Wilis. Adanya kegiatan ini diharapkan wilayah hutan lindung kaki Gunung Wilis terhindar dari kerusakan akibat pembangunan Jalur Lingkar Wilis dan ketersediaan air di Kabupaten Tulungagung terus terjaga.

Kata kunci: reboisasi, Jalur Lingkar Wilis, resapan air 
Wahyu Perdana, dkk.: Reboisasi Jalur Lingkar Wilis: Sebuah Usaha Mempertahankan Daerah Resapan Air di Kabupaten Tulungagung Jawa Timur

\section{PENDAHULUAN}

Kecamatan Sendang adalah wilayah dataran tinggi yang terletak di Kabupaten Tulungagung. Pada kecamatan Sendang terdapat pegunungan Wilis yang merupakan salah satu daerah resapan air yang sangat diperlukan masyarakat Kabupaten Tulungagung. Daerah pegunungan dan dataran tinggi merupakan daerah penampung resapan air hujan yang harus dijaga kelestariannya. Hutan di wilayah pegunungan berperan dalam pengaturan kelembaban udara regional, aliran air sungai, pengurangan erosi dan sedimentasi (Sumedi dkk., 2012). Untuk menjaga kelestarian hutan, perlu dilakukan reboisasi. Penghijauan juga dapat bertujuan untuk peremajaan hutan, mengawetkan tanah, dan meningkatkan produktivitas hutan (Suryani, 2017).

Hutan sebagai tempat penampungan dan penyimpanan air hujan, sehingga air hujan dapat tersimpan dalam tanah dan tidak terbuang secara percuma atau disebut juga fungsi hidrologis (Kusumaningtyas dan Ivan, 2013). Hutan yang merupakan kawasan resapan air dapat berfungsi sebagai penyaring air tanah. Proses penyaringan air dari partikelpartikel yang terlarut terjadi ketika air masuk ke daerah resapan. Perjalanan air yang terjadi di dalam tanah memerlukan waktu yang relatif lama. Daerah resapan air merupakan daerah tempat meresapnya air hujan ke dalam tanah yang selanjutnya akan menjadi air tanah (Gunawan dkk, 2016). Kawasan yang sulit atau tidak dapat menyerap air akan mengakibatkan aliran air langsung menuju ke sungai dan laut tanpa disertai penyerapan air ke dalam tanah (Gunawan dkk, 2016).

Hutan lindung jalur lingkar Wilis, terdiri dari 3 lapisan, yaitu (1) lapisan tanah, (2) air, dan (3) kawah. Untuk menjaga agar kawah tidak naik ke permukaan, maka reboisasi harus terus dilakukan dengan memperhatikan pemilihan jenis tanaman untuk peremajaan hutan tersebut (Suryani, 2017). Dengan melakukan reboisasi akan didapatkan manfaat seperti: mencegah terjadinya erosi tanah yang disebabkan oleh angin dan air hujan yang berturut-turut, membuat tanah tetap kokoh sehingga risiko tanah longsor bisa dihindari, mengurangi global warming dan pencemaran udara.

Jalur Lingkar Wilis adalah jalur yang menghubungkan enam kabupaten di Jawa Timur, mulai dari Kabupaten Nganjuk, Ponorogo, Kabupaten Madiun, Tulungagung, Trenggalek, dan Kediri. Jalur ini melewati daerah kaki Gunung Wilis yang merupakan daerah hutan lindung yang terletak di Desa Geger, Kecamatan Sendang. Hal ini membuat sebagian wilayah dari hutan lindung mengalami penggundulan akibat pembangunan Jalur Lingkar Wilis.

Permasalahan tersebut menyebabkan daerah resapan air di Desa Geger pada khususnya dan di Kabupaten Tulungagung pada umumnya mengalami penurunan, sehingga reboisasi secara berkala sangat perlu untuk dilaksanakan demi terjaganya daerah resapan air dan ketersediaan air bersih di Kabupaten Tulungagung.

\section{METODE PENGABDIAN MASYARAKAT}

\section{Penyuluhan}

Peserta yang hadir adalah masyarakat desa Geger, pejabat Perhutani Tulungagung, komunitas Peduli Hutan Lindung Sendang, komunitas Tulungagung Society, dan komunitas Pecinta Alam SMPN 1 Sendang. 
Materi penyuluhan yang diberikan adalah tentang pentingnya reboisasi dalam kawasan hutan lindung. Beberapa aspek yang harus diperhatikan untuk pada proses reboisasi adalah: (1) menentukan lokasi kegiatan reboisasi, (2) menentukan jenis tanaman, (3) dan cara bertanam dan pemupukan yang benar.

\section{Bibit tanaman yang dipergunakan}

Bibit tanaman pete, nagka, dan alpukat yang diperoleh dari pihak Perhutani Tulungagung, dan bibit tanaman pule merupakan sumbangan dari pihak komunitas peduli hutan lindung Sendang.

\section{HASIL DAN PEMBAHASAN}

Masyarakat sangat antusias pada kegiatan penyuluhan reboisasi, hal ini terlihat dari banyaknya pertanyaan yang diajukan selama penyuluhan berlangsung. Penyuluhan ini dimaksudkan supaya masyarakat mendapatkan wawasan dan pemahaman yang terkait dengan pentingnya reboisasi.

Pada saat pelaksanaan program reboisasi, bibit tanaman produktif yang diplih adalah pete, nangka, dan alpukat yang diperoleh dari pihak Perhutani Tulungagung, sedangkan bibit tanaman pule merupakan sumbangan dari pihak komunitas peduli hutan lindung Sendang. Total pohon yang telah ditanam jalur lingkar Wilis serta sebagian hutan lindung desa Geger, Kecamatan Sendang sebanyak 220 pohon.

Kegiatan reboisasi dengan tanaman produktif, yang telah dilakukan secara gotong royong oleh mahasiswa KKN Universitas Airlangga dengan masyarakat desa Geger, pejabat Perhutani Tulungagung, komunitas Peduli Hutan Lindung Sendang, komunitas Tulungagung Society, dan komunitas Pecinta Alam SMPN 1 Sendang ini, diharapkan dapat meningkatkan ketersediaan air tanah di wilayah sekitar lingkar Wilis dan di kemudian hari dapat menjadi sumber penghasilan tambahan untuk masyarakat sekitar.

Jadi upaya program reboisasi ini dapat mempertahankan daerah resapan air mengingat Kecamatan Sendang merupakan salah satu kecamatan pemasok sumber air bersih di Kabupaten Tulungagung. Adanya program ini diharapkan dapat menjadi pemantik bagi komunitas-komunitas lain terutama mahasiswa untuk peduli terhadap lingkungan utamanya yaitu ketersediaan daerah resapan air demi kelangsungan air bersih untuk masyarakat.

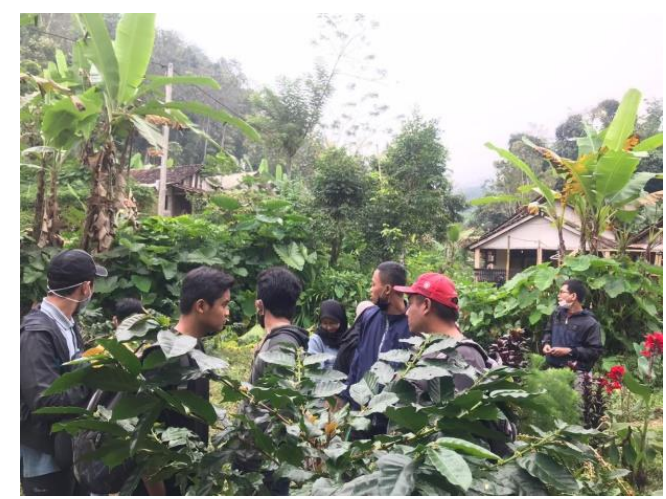

Gambar 1. Survey lapangan

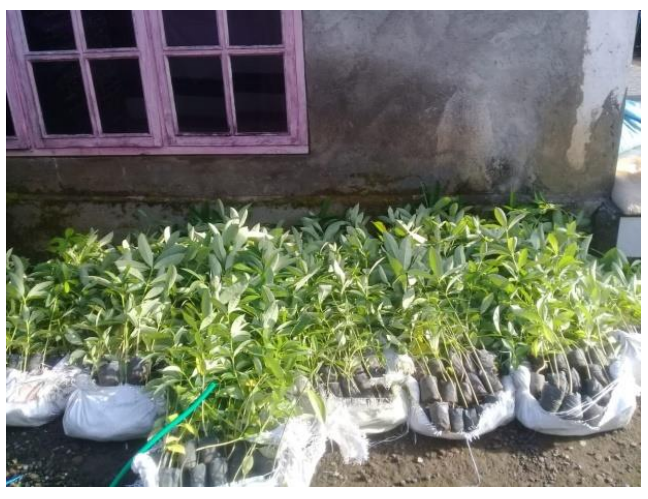

Gambar 2. Bibit tanaman pule 
Wahyu Perdana, dkk.: Reboisasi Jalur Lingkar Wilis: Sebuah Usaha Mempertahankan Daerah Resapan Air di Kabupaten Tulungagung Jawa Timur

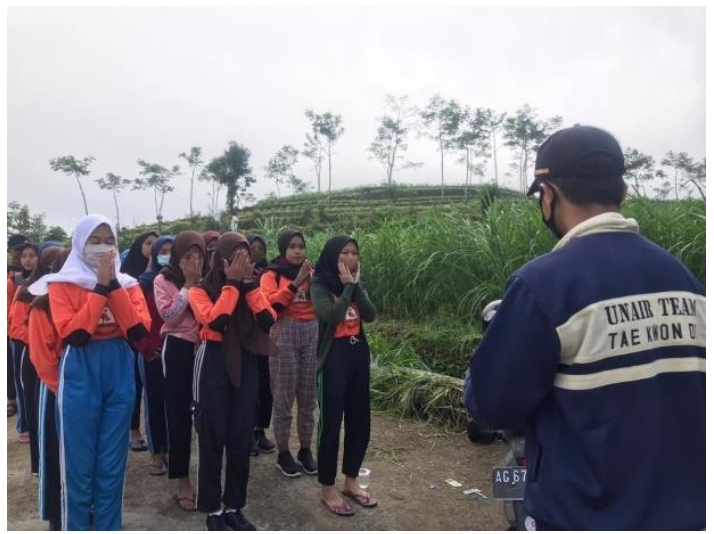

Gambar 3. Persiapan pelaksanaan kegiatan
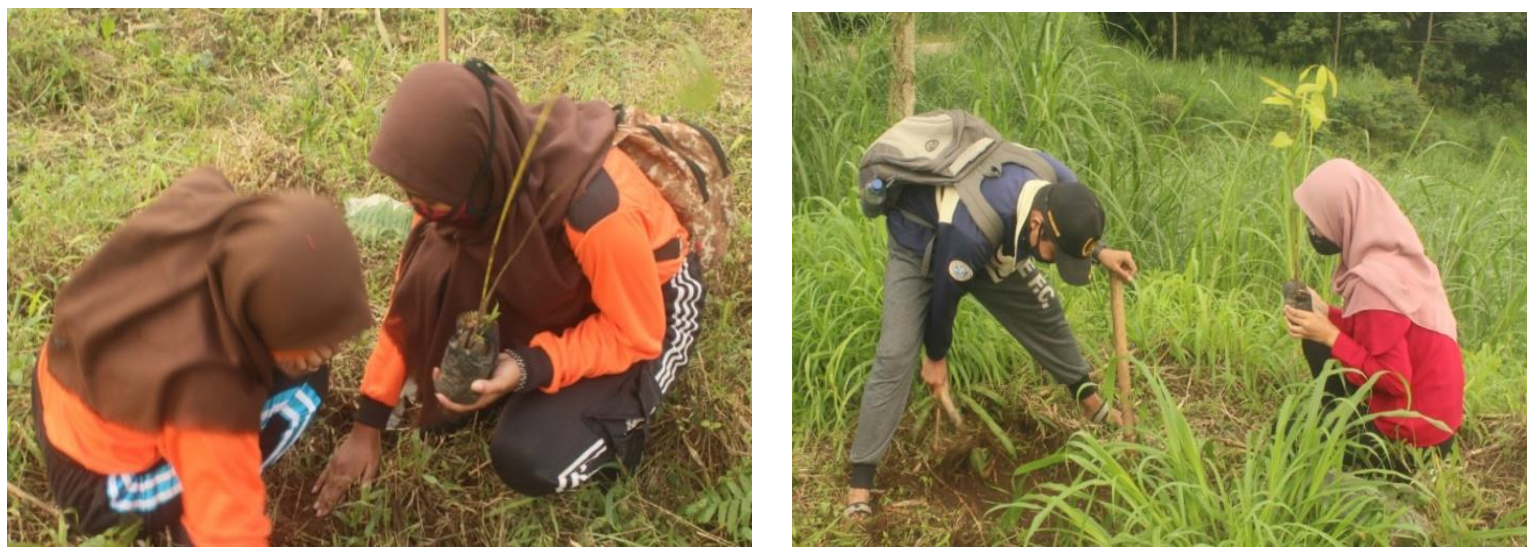

Gambar 4,5 : Pelaksanaan kegiatan penanaman bibit pohon

\section{PENUTUP}

\section{Simpulan}

Kegiatan pengabdian masyarakat ini dilakukan untuk pelestarian wilayah hutan yang merupakan daerah resapan air, dengan dilakukan reboisasi ini daerah resapan air di wilayah Tulungagung tetap terjaga, dan hasil hutan dapat meningkatkan perekonomian masyarakat sekitar. Dengan demikian diharapkan wilayah hutan lindung kaki Gunung Wilis terhindar dari kerusakan akibat pembangunan jalur lingkar Wilis.

\section{Saran}

Pada kegiatan pengabdian masyarakat ini diharapkan dapat menjadi pemantik bagi komunitas-komunitas lain terutama mahasiswa untuk peduli terhadap lingkungan utamanya terhadap ketersediaan daerah resapan air demi kelangsungan air bersih untuk masyarakat sehingga kegiatan reboisasi menjadi kegiatan yang berkelanjutan yang dilakukan oleh berbagai pihak. 


\section{UCAPAN TERIMA KASIH}

Ucapan terima kasih kepada Kepala Desa Geger, Bapak Bambang selaku ketua Perhutani Tulungagung, Bapak Slamet selaku ketua komunitas Peduli Hutan Lindung Sendang, komunitas Tulungagung Society, dan komunitas Pecinta Alam SMPN 1 Sendang, dan semua pihak yang telah berpartisipasi mensukseskan kegiatan ini.

\section{DAFTAR PUSTAKA}

Gunawan, S. A., Prasetyo, Y., \& Amarrohman , F. J. (2016). Studi Penentuan Kawasan Resapan Air Pada Wilayah Das Banjir Kanal Timur. Jurnal Geodesi Undip, 125-135.

Kusumaningtyas, R., Ivan C. 2013. Pengelolaan Hutan Dalam Mengatasi Alih Fungsi Lahan Hutan Di Wilayah Kabupaten Subang. Jurnal Perencanaan Wilayah dan Kota, 13(2):2-11.

Sumedi, N., Hasanu S., Djuwantoko. 2012. Strategi Pengelolaan Pegunungan Jawa : Studi Kasus Pegunungan Dieng Jawa Tengah, Indonesia. Jurnal Penelitian Kehutanan Wallacea 1(1): 36-49

Suryani, Ade Irma. (2017). Reboisasi/Penghijauan (Peran Serta Masyarakat Dalam Penanggulangan Bencana Longsor). Jurnal Penelitian, Terapan Ilmu Geografi, dan Pendidikan Geografi, 1-9.

Pemerintah Desa Geger. (2019). Profil Desa Geger. Retrieved 7 20, 2020, from geger.tulungagungdaring.id: http://www.geger.tulungagungdaring.id/profil 